International Journal of Current Microbiology and Applied Sciences

ISSN: 2319-7706 Volume 10 Number 10 (2021)

Journal homepage: http://www.ijcmas.com

\title{
Influence of fungicide and fertilizer amendments on mycorrhizal association in Quiona (Chenopodium quinoa. Willd.)
}

\author{
Prashanthisandepogu* \\ Department of Botany, TSWRDC (W), Mahendrahills, Hyderabad, India \\ *Corresponding author
}

\begin{tabular}{|c|c|}
\hline \multicolumn{2}{|r|}{ A B S T R A C T } \\
\hline Keywords & \\
\hline $\begin{array}{l}\text { Bavistin + Thiram, } \\
\text { Difolatan and } \\
\text { Thiram, } \\
\text { Chenopodium } \\
\text { quinoa Willd, } \\
\text { Glomus, Gigaspora, } \\
\text { PYM and FYM } \\
\end{array}$ & \multirow{3}{*}{$\begin{array}{l}\text { Effect of soil factor like alkaline cultivated versus saline non-cultivated } \\
\text { soil, fertilization with organic (PYM) and inorganic (DAP) manure and } \\
\text { addition of fungicides (Bavistin + Thiram, Difolatan and Thiram) on } \\
\text { indigenous VA mycorrhizal fungi was examined in Quinoa (Chenopodium } \\
\text { quinoa Willd). DAP in combination with Bavistin + Thiram enhanced the } \\
\text { spore population ad decreased mycorrhizal formation. FYM in combination } \\
\text { with Difolatan enhanced both. Adverse effects of fungicides were nullified } \\
\text { by fertilizers. Activity of Glomus was enhanced in the presence of DAP and } \\
\text { Gigaspora was favoured by FYM. }\end{array}$} \\
\hline Article Info & \\
\hline $\begin{array}{l}\text { Accepted: } \\
\text { 15 September } 2021 \\
\text { Available Online: } \\
10 \text { October } 2021\end{array}$ & \\
\hline
\end{tabular}

\section{Introduction}

Changing agricultural practices have resulted in increased pesticides and fertilizer usage. The benefits of fungicides (increased crop growth via destruction of pathogens) may be diluted by harmful effects on beneficial microbes like mycorrhizal fungi (Md. Wasim Aktar et al., 2009). Similarly, the effects of mineral and organic fertilizers and of different types of soils on the frequency of VA mycorrhizal fungi are well documented. The minerals like $\mathrm{N}$ and $\mathrm{P}$ are also essential for the plant growth which fixes by the VAM fungi. Just as for fungal growth may be restricted when soil nutrient availability falls below a certain threshold. Under these circumstances, $\mathrm{N}$ or $\mathrm{P}$ additions may increase mycorrhizal growth. Because mycorrhizal fungi are more efficient scavengers for the uptake of nutrients from the soil than plant roots (Allen, 1991).

According to J. Beltrano et.al. (2013) Mycorrhizal infections are capable of facilitating the damage of salt stress and promote plant growth. However, evidence that influence of fungicide-fertilizer interaction on VA mycorrhizae has never been considered. This information is vital for rational use of fungicides in disease control without adversely affecting growth promoting mycorrhizal associations.

The present study was undertaken to explore the potentials of such interaction in influencing of mycorrhizal status of Chenopodium quinoa. Willd grown in cultivated alkaline and non-cultivated 
saline soils, amended with inorganic and organic fertilizers, with seeds treated with fungicides normally used to control soil-borne pathogens.

\section{Materials and Methods}

\section{Soil amendments with fertilizers}

Soil was collected from cultivated and noncultivated areas of Telangana University, Nizamabad area and analysed for $\mathrm{pH}$, EC (measure of total soluble salts), potassium, $\mathrm{CaCo} 3$ and texture by Agriculture Research Institute, Rajendranagar,hyderabad. Frmyard manure (FYM) was mixed in the ratio of $1: 5$ and Diammonium phosphate (DAP) was added 70 $\mathrm{kg} / \mathrm{ha}$.

\section{Seed treatment with fungicides}

Seeds of Quinoa were treated with Bavistin + Thiram, Difolatan and Thiram 0.25\%. 50g seed was taken in each case in a conical flask and 135 $\mathrm{mg}$ fungicides was added. The flasks were corked with cotton plug encased in the butter paper and shaken well to ensure uniform coating of fungicides on the seed. The treated seeds were kept for 24 hours before sowing.

\section{Quantification of spore population in soil and mycorrhizal in plant roots}

For assessment of spore population the wet sieving and decanting technique (Gerdemann and Nicolson, 1963) was used. The types and number of mycorrhizal spores was observed and recorded under stereoscopic binocular microscope. Mycorrhizal in plant roots was quantified by the method of Giovanneti and Mosse (1980).

\section{Treatment}

1.Control (soil alone)

2. Plus Farmyard manure (FYM)

3. Plus Diammonium phosphate (DAP)

4. Plus Bavistin + Thiram

5. Plus Difolatan

6. Plus Thiram

7. $2+4$

8. $2+5$
9. $2+6$

10. $3+4$

11. $3+5$

12. $3+6$

10 inch pots were filled with cultivated / noncultivated soil and the fertilizer treatments applied. Fungicides were applied as seed dressing. 5 seeds of Chenopodium quinoa_Willd.were sown in each pot. Each treatment was replicated thrice. Data on spore population of endogonaceous fungi and percentage of mycorrhizal colonization in roots was recorded after 30 days.

\section{Results and Discussion}

\section{The Substrate}

Two types of soils, namely cultivated and noncultivated were used. Both had sandy loam texture and similar organic carbon content and EC. Potassium and phosphorus content were higher in cultivated soil which was alkaline in nature as compared to saline nature of non-cultivated soil (Table 1).

Spore population of mycorrhizal fungi was higher in cultivated soil ( $15 \mathrm{spores} / 5 \mathrm{gm}$ soil) as compared to non-cultivated one $(10 / 5 \mathrm{gm})$. Amendments did not alter this trend (Table 2). Mycorrhizal root development was also more in cultivated soil. Two mycorrhizal fungi namely Glomus and Gigaspora were found in both types of soils with former dominating. Both genera had two distinct types of spores. However, in the absence of positive identification at species level, the results have been evaluated at genus level, even though the distribution of all spore types have been indicated in Table 2 and graphs.

\section{DAP vS. FYM}

Amendment with DAP favoured dominance of Gigaspora over Glomus in cultivated soil while in non-cultivated substrate it further enhanced the dominance of Glomus to the extent that Gigaspora.

FYM eliminated Gigaspora in cultivated soil was found to be a better substrate than non-cultivated 
soil for the development of mycorrhizal roots. DAP amendment had a retarding effect on mycorrhizal formation in cultivated soil while in non-cultivated soil it enhanced this activity. FYM reversed the trend in two types of soils. In general, amendment of cultivated soil with DAP and noncultivated soil with FYM enhanced the production of spores and reduced the mycorrhizal root formation.

\section{Fertilizer-Fungicide Interactions}

The trends of reduction of spore population in the presence of fungicides was reversed when DAP was added to cultivated soil containing one or the other of three fungicides, so much so that total number of spores increased by $50-60 \%$ over initial population in un amended soil. Similar trend was observed in non-cultivated soil also expect in case of DAP + Thiram where there was on effect. Addition of FYM did not reverse the trend in cultivated soil but in non-cultivated soil the spore's production was enhanced in FYM + Thiram and FYM + Difolatan treatments by $10 \%$ and $30 \%$ respectively (Table 3 ). In the presence of fungicides FYM enhanced production of Gigaspora spores and DAP increased Glomus spore population, in saline soil. The spore population of Gigaspora in alkaline soil was increased in the presence of both DAP and Difolatan but the endophyte was eliminated when the two were applied together. cultivated (alkaline) and non-cultivated (alkaline) soils. For example, against $15 / 5 \mathrm{gm}$ spores in un amended cultivated soil only 10/5gm were recorded when Bavistin + Thiram was added (Table 2 \& 3; Graphs 2a \& 2b). The dominance of Glomus over Gigaspora was unaffected in the presence of any of the three fungicides however mycorrhizal root development continued to be retarded when fertilizer was added to fungicide containing soils. However, DAP nullified the adverse effect of Thiram in non-cultivated soil. Table. 3 showing results of percentage increased (I)/ decreased (D) of spores and mycorrhizal roots in amended soils over control in Chenopodium quinoa Willd.

\section{Fungicides}

Presence of any three fungicides (Bavistin + Thiram, Difolatan, Thiram) not only reduces the production of mycorrhizal spores but also retarded mycorrhizal formation in both cultivated soils (alkaline) and non-cultivated (alkaline) soils. For example, against $15 / 5 \mathrm{gm}$ spores in un amended cultivated soil only $10 / 5 \mathrm{gm}$ were recorded when Bavistin + Thiram was added (Table 2 \& 3; Graphs 2a \& 2b). The dominance of Glomus over Gigaspora was unaffected in the presence of any of the three fungicides and FYM reversed the trend from retardation to enhancement in both types of soils containing either Thiram or Difolatan. FYM + Difolatan resulted in significant increase in mycorrhizal roots from $30 \%$ to $100 \%$ where as FYM = Thiram showed only marginal benefit of less than $10 \%$ (Table 3).

Table.1 Soil analysis of cultivated and non cultivated soil

\begin{tabular}{|c|c|c|c|c|c|c|c|c|c|c|}
\hline \multirow[t]{2}{*}{ S.No } & \multirow[t]{2}{*}{ Type of soil } & \multirow{2}{*}{$\begin{array}{c}\text { pH } \\
\text { (soil } \\
\text { reaction) }\end{array}$} & \multirow[t]{2}{*}{$\begin{array}{c}\text { EC* } \\
(\mathbf{m m h o} / \mathbf{c m})\end{array}$} & \multirow{2}{*}{$\begin{array}{c}\text { Org } \\
\text { Carbon } \\
\% * *\end{array}$} & \multirow{2}{*}{$\begin{array}{c}\text { Av.phosphorus } \\
\text { (1 b/ac) } \\
\text { (x1.12=kg } \\
\text { P/ha) }\end{array}$} & \multirow{2}{*}{$\begin{array}{c}\text { Av.potash } \\
\text { (1 b/ac) } \\
\text { (x1.12xkg } \\
\text { K/ha) }\end{array}$} & \multirow[t]{2}{*}{$\mathrm{CaCo}$} & \multirow[t]{2}{*}{ Texture } & \multicolumn{2}{|c|}{$\begin{array}{c}\text { Quantitative } \\
\text { analysis of } 5 \mathrm{gm} \text { soil }\end{array}$} \\
\hline & & & & & & & & & $\begin{array}{l}\text { No. of } \\
\text { spores }\end{array}$ & $\begin{array}{l}\text { Types of } \\
\text { spores }\end{array}$ \\
\hline A. & $\begin{array}{l}\text { Cultivated } \\
\text { soil } \\
\text { (Alkali soil) }\end{array}$ & 8.7 & 0.15 & 0.40 & 8.0 & 235 & Medium & $\begin{array}{l}\text { Sandy } \\
\text { loam }\end{array}$ & 15 & $\begin{array}{l}4 a \\
9 b \\
2 c\end{array}$ \\
\hline B. & $\begin{array}{l}\text { Non- } \\
\text { cultivated } \\
\text { soil (Saline } \\
\text { soil) }\end{array}$ & 8.1 & 1.1 & 0.40 & 6.4 & 200 & Low & $\begin{array}{l}\text { Sandy } \\
\text { loam }\end{array}$ & 10 & $\begin{array}{l}4 a \\
5 b \\
1 c\end{array}$ \\
\hline
\end{tabular}

*Measure of total soluble salts.

**Measure of available soil nitrogen.

***Approximate values by rapid determination. $\mathrm{c}=$ large black spores (Gigaspora $\mathrm{sp}$.) $\mathrm{a}=$ small black spores (Glomus macrocarpum)

$\mathrm{b}=$ small yellow spores (Glomus microcarpus) 
Graph for Table.1 Soil analysis of cultivated and non cultivated soil

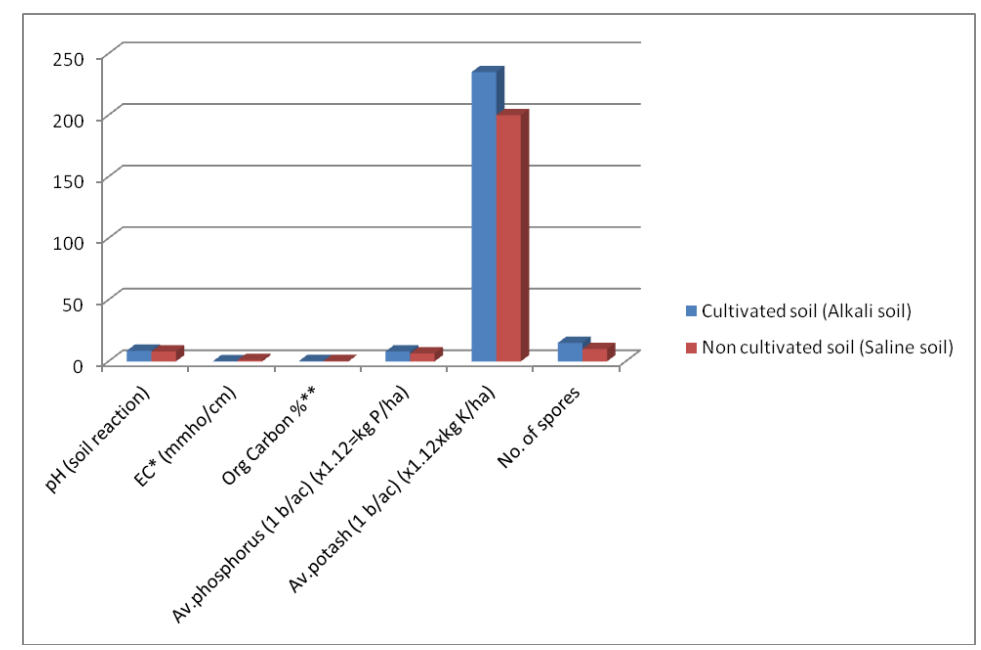

Table.2 Effect of different soil amendments on mycorrhizal development in Quinoa (Chenopodium quinoa Willd.)

\begin{tabular}{|l|l|c|c|c|}
\hline S.No. & \multicolumn{1}{|c|}{ Treatment } & Percentage & Spores per 5gm soil & Types of spores \\
\hline $\mathbf{1}$ & $\mathrm{CP}_{0}$ & 90.9 & 15 & $4 \mathrm{a}, 9 \mathrm{~b}, 2 \mathrm{c}$ \\
$\mathbf{2}$ & $\mathrm{CP}_{1}$ & 100.0 & 10 & $6 \mathrm{a}, 4 \mathrm{~b}$ \\
$\mathbf{3}$ & $\mathrm{CP}_{2}$ & 56.25 & 14 & $6 \mathrm{a}, 5 \mathrm{~b}, 2 \mathrm{c}, 1 \mathrm{~d}$ \\
$\mathbf{4}$ & $\mathrm{CP}_{3}$ & 66.6 & 12 & $6 \mathrm{a}, 4 \mathrm{~b}, 2 \mathrm{c}$ \\
$\mathbf{5}$ & $\mathrm{NCP}_{0}$ & 47.2 & 10 & $4 \mathrm{a}, 5 \mathrm{~b}, 1 \mathrm{c}$ \\
$\mathbf{6}$ & $\mathrm{NCP}_{1}$ & 33.3 & 10 & $6 \mathrm{a}, 4 \mathrm{~b}$ \\
$\mathbf{7}$ & $\mathrm{NCP}_{2}$ & - & - & \\
$\mathbf{8}$ & $\mathrm{NCP}_{3}$ & 39.3 & 9 & $3 \mathrm{a}, 6 \mathrm{~b}$ \\
$\mathbf{9}$ & CDAPP $_{0}$ & 80.9 & 18 & $9 \mathrm{a}, 1 \mathrm{~b}, 8 \mathrm{~d}$ \\
$\mathbf{1 0}$ & CDAPP $_{1}$ & 58.3 & 22 & $9 \mathrm{a}, 7 \mathrm{~b}, 6 \mathrm{c}$ \\
$\mathbf{1 1}$ & CDAPP $_{2}$ & 80.0 & 15 & $12 \mathrm{a}, 3 \mathrm{~b}$ \\
$\mathbf{1 2}$ & CDAPP $_{3}$ & 80.0 & 16 & $12 \mathrm{a}, 4 \mathrm{~b}$ \\
$\mathbf{1 3}$ & NCDAPP $_{0}$ & 85.7 & 16 & $10 \mathrm{a}, 6 \mathrm{~b}$ \\
$\mathbf{1 4}$ & NCDAPP $_{1}$ & 12.5 & 14 & $10 \mathrm{a}, 4 \mathrm{~b}$ \\
$\mathbf{1 5}$ & NCDAPP $_{2}$ & 25.0 & 14 & $5 \mathrm{a}, 9 \mathrm{~b}$ \\
$\mathbf{1 6}$ & NCDAPP $_{3}$ & 58.3 & 9 & $4 \mathrm{a}, 5 \mathrm{~b}$ \\
$\mathbf{1 7}$ & CFYMP $_{0}$ & 100.0 & 14 & $8 \mathrm{a}, 6 \mathrm{~b}$ \\
$\mathbf{1 8}$ & CFYMP $_{1}$ & 30.0 & 13 & $6 \mathrm{a}, 7 \mathrm{~b}$ \\
$\mathbf{1 9}$ & CFYMP $_{2}$ & 100.0 & 13 & $10 \mathrm{a}, 3 \mathrm{~b}$ \\
$\mathbf{2 0}$ & CFYMP $_{3}$ & 37.5 & 8 & $7 \mathrm{a}, 1 \mathrm{~b}$ \\
$\mathbf{2 1}$ & NCFYMP $_{0}$ & 30.0 & 8 & $2 \mathrm{a}, 5 \mathrm{~b}, 1 \mathrm{c}$ \\
$\mathbf{2 2}$ & NCFYMP $_{1}$ & 37.5 & 7 & $3 \mathrm{a}, 4 \mathrm{~b}$ \\
$\mathbf{2 3}$ & NCFYMP $_{2}$ & 100.0 & 13 & $5 \mathrm{a}, 2 \mathrm{~b}, 6 \mathrm{c}$ \\
$\mathbf{2 4}$ & NCFYMP $_{3}$ & 35.7 & 11 & $4 \mathrm{a}, 3 \mathrm{~b}, 4 \mathrm{c}$ \\
\hline
\end{tabular}


Graph for Table.2 Effect of different soil amendments on mycorrhizal development in Quinoa (Chenopodium quinoa Willd.)

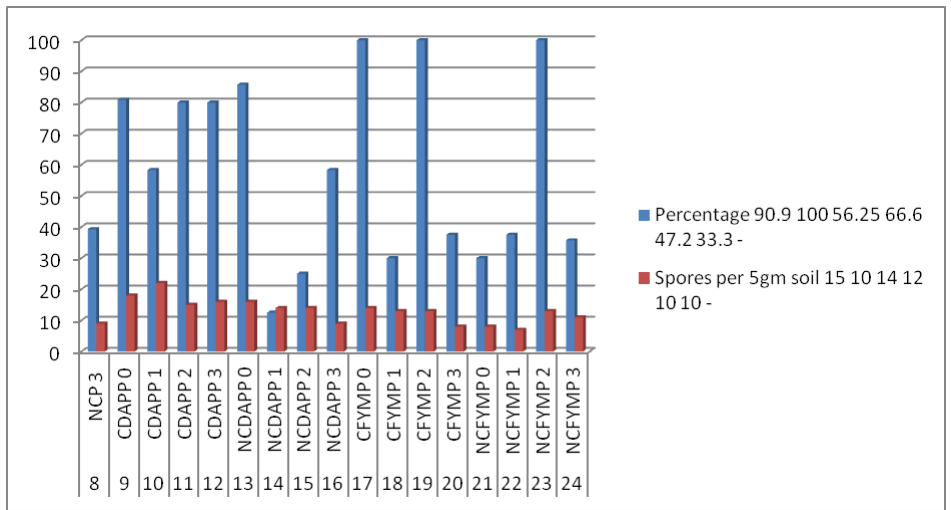

Table.3 Percentage increased (I), decreased (D) of spores in Mycorrhizal roots of Quinoa over control Graph for

\begin{tabular}{|c|c|c|c|c|c|c|c|c|}
\hline \multirow[b]{2}{*}{ Treatment } & \multicolumn{3}{|c|}{ Cultivated spores (No) } & \multirow[b]{2}{*}{$\begin{array}{c}\text { Mycorrhizal } \\
\text { Roots }\end{array}$} & \multicolumn{3}{|c|}{ Non Cultivated spores (No) } & \multirow[b]{2}{*}{$\begin{array}{c}\text { Mycorrhizal } \\
\text { Roots }\end{array}$} \\
\hline & Total & Glomus & Gigaspora & & Total & Glomus & Gigaspora & \\
\hline $\begin{array}{l}\text { DAP } \\
\text { DAP + Bavistin + Thiram } \\
\text { DAP + Difolatan } \\
\text { DAP + Thiram }\end{array}$ & $\begin{array}{c}30(\mathrm{I}) \\
50(\mathrm{I}) \\
\text { No effect } \\
65(\mathrm{I})\end{array}$ & $\begin{array}{l}25(\mathrm{D}) \\
6.6(\mathrm{I}) \\
15(\mathrm{I}) \\
22(\mathrm{I})\end{array}$ & $\begin{array}{c}350(\mathrm{I}) \\
300(\mathrm{I}) \\
\text { Eliminated } \\
\text { Eliminated }\end{array}$ & $\begin{array}{l}10(\mathrm{D}) \\
35(\mathrm{D}) \\
12(\mathrm{D}) \\
12(\mathrm{D})\end{array}$ & $\begin{array}{l}60(\mathrm{I}) \\
40(\mathrm{I}) \\
40(\mathrm{I}) \\
10(\mathrm{D})\end{array}$ & $\begin{array}{c}77(\mathrm{I}) \\
55(\mathrm{I}) \\
55(\mathrm{I}) \\
\text { No effect }\end{array}$ & $\begin{array}{l}\text { Eliminated } \\
\text { Eliminated } \\
\text { Eliminated } \\
\text { Eliminated }\end{array}$ & $\begin{array}{l}80(\mathrm{I}) \\
80(\mathrm{D}) \\
50(\mathrm{D}) \\
29(\mathrm{I})\end{array}$ \\
\hline $\begin{array}{l}\text { Bavistin + Thiram } \\
\text { Difolatan } \\
\text { Thiram }\end{array}$ & $\begin{array}{l}33(\mathrm{D}) \\
6.6(\mathrm{D}) \\
20(\mathrm{D})\end{array}$ & $\begin{array}{l}22(\mathrm{D}) \\
15(\mathrm{D}) \\
22(\mathrm{D})\end{array}$ & $\begin{array}{l}\text { Eliminated } \\
50(\mathrm{I}) \\
\text { No effect }\end{array}$ & $\begin{array}{c}10(\mathrm{I}) \\
36.5(\mathrm{D}) \\
29(\mathrm{D})\end{array}$ & $\begin{array}{l}\text { No effect } \\
6(\mathrm{D}) \\
10(\mathrm{D})\end{array}$ & $\begin{array}{c}11(\mathrm{I}) \\
12(\mathrm{D}) \\
\text { No effect }\end{array}$ & $\begin{array}{l}\text { Eliminated } \\
\text { Eliminated } \\
\text { Eliminated }\end{array}$ & $\begin{array}{l}40(\mathrm{D}) \\
23(\mathrm{D}) \\
12(\mathrm{D})\end{array}$ \\
\hline $\begin{array}{l}\text { FYM } \\
\text { FYM + Bavistin Thiram } \\
\text { FYM + Difolatan } \\
\text { FYM + Thiram }\end{array}$ & $\begin{array}{l}6.5(\mathrm{D}) \\
14(\mathrm{D}) \\
14(\mathrm{D}) \\
45(\mathrm{D})\end{array}$ & $\begin{array}{c}8(\mathrm{I}) \\
\text { No effect } \\
\text { No effect } \\
38(D)\end{array}$ & $\begin{array}{l}\text { Eliminated } \\
\text { Eliminated } \\
\text { Eliminated } \\
\text { Eliminated }\end{array}$ & $\begin{array}{c}11(\mathrm{I}) \\
66(\mathrm{D}) \\
120(\mathrm{I}) \\
15.5(\mathrm{D})\end{array}$ & $\begin{array}{c}20(\mathrm{D}) \\
30(\mathrm{D}) \\
30(\mathrm{I}) \\
10(\mathrm{I})\end{array}$ & $\begin{array}{l}30(\mathrm{D}) \\
23(\mathrm{D}) \\
22(\mathrm{D}) \\
22(\mathrm{D})\end{array}$ & $\begin{array}{c}\text { No effect } \\
\text { Eliminated } \\
600 \\
500\end{array}$ & $\begin{array}{l}66(\mathrm{D}) \\
15(\mathrm{D}) \\
120(\mathrm{I}) \\
20(\mathrm{D})\end{array}$ \\
\hline
\end{tabular}

Table.3 Percentage increased (I), decreased (D) of spores in Mycorrhizal roots of

Quinoa over control

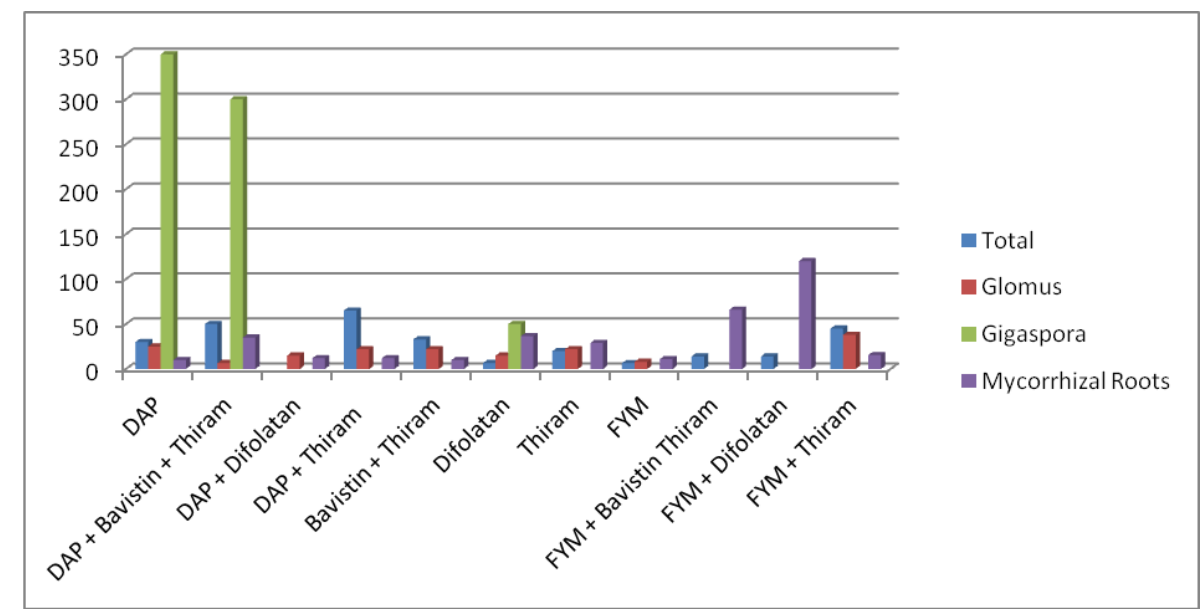

The fungi that form vesicular-arbuscular mycorrhizae have extremely wide host range and there is no definitive evidence that places any restriction on the host range of any particular species provided the host is capable of forming vesicular-arbuscular mycorrhizal associations.
Most spore types of this group of microorganisms seem to have a worldwide distribution. The spores were generally more numerous and varied in cultivated than in non-cultivated soils of Kalaburagi District, Karnataka (Mousumi Das et.al 2015). Muthukumar et al. (2003) observed that 
root density, AM colonization and AM fungal spore numbers decreased with soil depth in all forests in Xishuangbanna, in southwest China and similar observation was made by Douds et al.(1995). Spore populations have been found to decrease with increasing clay content, increase with increasing $\mathrm{pH}$ and carbon, and decrease with increasing soil phosphorus ( S. C. Tiwari S. S. Singh 2003 ). Three genera of AM fungi were usually found in rhizosphere soils of crops plants, Glomus mosseae was the most frequent mycorrhizal associate N. Valsalakumar et.al., (2007), Gigaspora spp., was another fungus found by them, but not as frequently as Glomus. In the present studies 4 types, two each of Glomus and Gigaspora were observed irrespective of the types of soil, namely alkaline cultivated and saline noncultivated. Higher spore population was recorded in cultivated soil than in non-cultivated one. Similar results were obtained by Abbott and Robson (1982). The percentage of root becoming mycorrhizal was also more in the cultivated soil than in the non-cultivated soil in which Quinoa was grown. As evident from the present studies the $\mathrm{pH}$ of the soil does not seem to influence the spore types and consequently the mycorhizal fungus species. Occurrence of only Glomus and Gigaspora in lateritic soils of Andhra Pradesh suggests that probably these fungi are most common in Indian soils. Dominance of Glomus in the results obtained from the present studies is in conformity with results obtained by other workers in India ( Poonam Verma and Verma 2017).

In cultivated soils vesicular-arbuscular mycorrhizal fungi are affected by various agricultural and horticultural practices particularly fertilizer addition, pesticide applications and crop rotations. Changes in soil fertility due to amendments with mineral fertilizer or organic matter can markedly affect the activity of the soil mycorrhizal population in terms of the amount of root infection and number of the spores produced (Mosse, 1973). In the present studies amendment with Diammonium Phosphate affected the spore types of both cultivated and non-cultivated soils. While in cultivated soil this fertilizer favoured spore production of Gigaspora over Glomus. The DAP had a retarding effect on the development of mycorrhizal roots in cultivated soil in which Quinoa was grown. However, in non-cultivated soil it enhanced this development. Similar reverse trend was seen with FYM. There is considerable information on the negative effects of nitrogen fertilizer on mycorrhiza formation. Understanding the effects of different agricultural practices on the mycorrhizal symbiosis is very important for agricultural production and the sustainable use of soil and investigations were made depending upon the composition and diversity of various arbuscular mycorrhizal fungi (AMF) in soils from fields of different agricultural practices Manoharan et al., (2017). The largest numbers of spores were formed at higher and low levels of nitrogen. To predict the effects of fertilizer amendment on the population of mycorrhizal fungi, some idea of the initial soil fertility is needed because in a very poor soil the spore production will be limited by the small amount of total, not the percent, root infection resulting from poor plant growth. Generally high soil fertility leads to little VAM infection so that we are unlikely to find much mycorrhizal in intensively cultivated soils. The use of fungicides to control soil-borne pathogens is a common thing. Recently, concern has developed among agriculturists about the effect of pesticide usage upon beneficial mycorrhizal fungi. Are the benefits of fungicides (increased crop growth via destruction of pathogenic organisms) being diluted because they also destroy mycorrhizal fungi and thereby reduce nutrient uptake by crop? The data now available on the interaction between mycorrhizal fungi and fungicides indicated that fungicides typically delay or reduce vesiculararbuscular mycorrhizal infection but rarely eliminated it (Menge, 1983). In the present study presence of any if the three fungicides, namely, Bavistin + Thiram (systemic fungicide, methyl 2 benzimidazole carbonate), Difolatan (heterocyclic nitrogenous compound, non-systemic in nature also known as Captafol) and Thiram (organic sulphur fungicide, non-systemic in nature) even though reduced both the spore population and mycorrhizal root development in both alkaline and saline soils, did not eliminate the symbiotic associations, However, the dominance of one fungus (Glomus) over another fungus (Gigaspora) was unaffected in all the treatments. It has been observed that non-systemic fungicides like PCNB, Thiram and Botran are consistently toxic to mycorrhizal fungi. In the present investigations the 
trends of reduction if spore population in the presence if fungicides was reversed when DAP was added to cultivated soil containing Bavistin Thiram. Similarly addition of FYM to noncultivated soil containing either Difolatan or Thiram enhanced the production of spores. In addition FYM + Difolatan resulted in significant increase in mycorrhizal roots in Quinoa. It appears that addition of FYM to saline soils can offset the harmful effect of Difolatan or Thiram on the production of mycorrhizal fungal spores or development of mycorrhizal roots. Since a large proportion of VA mycorrhizal hypae are inside roots it would appear that non-systemic fungicides can affect VAM primarily by inhibiting spore germination and infection processes and so are probably less damaging to mycorrhizal symbiosis than systemic fungicide. It is postulated that these (non-systemic) fungicides may be fungistastic but once the mycorrhizal fungus gains entry to the root these chemicals have little effect and may actually increase spread within the root. The effect of systemic fungicides upon VA mycorrhizal fungi were summarized by Menge (1983), According to him it was noteworthy that benzimidazole fungicides (to which Bavistin belongs) are toxic to VAM fungi although these fungicides are quite specific for higher ascomycetes but are relatively inefficient toward the zygomycetes with which the VAM fungi are classified.

\section{References}

Abbott LK, Robson AD (1991) Field management of VA mycorrhizal fungi. In: Kiester DL., Cregan PB (eds). The rhizophere and plant growth. Kluwer Academic Publishers, Dordrecht,pp 355 - 362.

Barbara Mosse, 1973. Plant growth responses to Vesicular-Arbuscular Mycorrhiza, New Pathologist, Volume 72, Issue No.1, January 1973, pages 127 136.

Beltrano, J., M. Ruscitti, M.C.Arango, M.Ronco, "Effects of arbuscular mycorrhiza inoculation on plant growth, biological and physiological parameters and mineral nutrition in pepper grown under different salinity and p levels", Journal of Soil Science and Plant Nutrition, 13(1), 123-141, 2013.

Douds, D.D., Jr., and N.C. Schenck. 1990. Relationship of colonization and sporulation by VAM fungus to plant nutrient and carbohydrate content. New Phytol. 116:621-627.

Gerdemann, J.W., and Nicolson, T., 1963. Spores of mycorrizal endogone species extracted from soil by wet-sieving and decanting. Trans. Bri.Mycol.Soc.

Giovanetti, M. and B. Mosse : An evaluation of techniques for measuring vesicular- arbuscular mycorrhizal infection in roots. New Phytol., 84, 489-500 (1980).

Hayman, D.S. 1983. The physiology of vesicular arbuscular mycorrhizal symbiosis. Can. J. Bot. 61:944-1.

Manoharan L., Rosenstock N.P., Williams A., Hedlund K. Agricultural management practices influence AMF diversity and community composition with cascading effects on plant productivity. Appl. Soil Ecol. 2017;115:53-59.

Md. Wasim Aktar et.al (2009), Impact of pesticides use in agriculture: their benefits and hazards, Interdiscip Toxicol. 2009 Mar; 2(1): 1-12. Published online 2009 Mar. doi: 10.2478/v10102-009-0001-7.

Menge, J.A. 1983. Utilization of vesicular-arbuscular mycorrhizal fungi in Agriculture. Can. J. Bot. 61:1015-1024. N. Valsalakumar et.al.,(2007), Arbuscular Mycorrhizal Fungi Associated with Green Gram in South India, Article in Agronomy Journal . September 2007 DOI: 10.2134/agronj2006.0367.

Muthukumar, T., Sha, L., Yang, X., Cao, M., Tang, J. and Zheng, Z. (2003). Distribution of roots and arbuscular mycorrhizal associations in tropical rain forest types of Xishuangbanna, southwest China. Appl. Soil Ecol., 22: 241-253. Abbott, L.K., and A.D. Robson. 1982. The role of VAM fungi in Agriculture and the selection of fungi for inoculation. Aust. J. Agric. Res. 33:389-408.

Poonam Verma and R.K. Verma, 2017. Species Diversity of Arbuscular Mycorrhizal (AM) Fungi in DalliRajhara Iron Mine Overburden Dump of Chhattisgarh (Central India), International Journal of Current Microbiology and Applied Sciences ISSN: 23197706 Volume 6 Number 4 (2017) pp. 2766-2781.

Tiwari, S. C., S. S. Singh 2003.Impacts on VesicularArbuscular Mycorrhizal (VAM) Fungi Diversity Associated with Degradation of Soils in Humid Tropical Forests, New Horizons in Biotechnology, 437-444, S. Roussos eta(eds) 2003 Kluwer Academic Publishers.

\section{How to cite this article:}

Prashanthisandepogu. 2021. Influence of fungicide and fertilizer amendments on mycorrhizal association in Quiona (Chenopodium quinoa. Willd.). Int.J.Curr.Microbiol.App.Sci. 10(10): 378-384. doi: https://doi.org/10.20546/ijcmas.2021.1010.046 